\title{
Status of E-learning Usage as Perceived by Jadara University Students - Jordan
}

\author{
Basam Mahmoud Ahmad Qablan \\ Department of Education Technology \\ Faculty of Education, Jadara University, B.O. Box: 733, Irbid 21110, Jordan \\ E-mail: bassammagableh@yahoo.com
}

Received: May 4, 2014 Accepted: March 24, 2015 Published: May 24, 2015

doi:10.5296/jse.v5i2.5581ＵRL: http://dx.doi.org/10.5296/jse.v5i2.5581

\begin{abstract}
This study aimed to identify the status of e-learning usage as perceived by Jadara University students, a total of (90) university students in the fourth -year at Jadara University participated in the study by completing the questionnaire designed by the researcher. Results indicated that there is no significant difference between the average scores of students on (the usage of students of the e-learning), the study results indicated that there was significant difference between the usage scores of students on the Domain of (advantage, Disadvantage and obstacle of e-learning) at Jadara University. And the study result shows a statistically significant difference between the average scores of students on the Domain of (the extent of using E-learning, and the positives) in favor of the scientific major, also results indicated that there is no a statistically significant difference between the average scores of students on the Domain of Disadvantage of e-learning, and constraints in regard speciality. In addition the results showed that the E-learning usage was moderate, and the uses of e-mail to communicate with teachers, and broadcasts of video and audio lectures of low use. and the highest advantage of using e-learning is the retention of information for long periods of time, while the highest Disadvantage of using e-learning is like a prolonged sitting in front of the computer causes a lot of diseases, beside that the highest obstacles was the lack of computer labs equipped with the necessary printers, headphones and paper.
\end{abstract}

Keywords: E-learning, Jadar University, Jordan 


\section{Introduction}

The advance of information technology and communication has led to the availability of information in all majors, the disappearance of distances between, information and the learner it has also led to the emergence of the need for sills, methods and technologies which have become on integral part of the life of the modern communities. To acquire knowledge itself is no longer the goal of education. The goals have become to acquire self- leaning skills and the ability to employ the information and the advanced technology in solving life problems.

The countries of the world have recently tended to draw plans for informatics and computer by integrating them in the educational curricula and the educational process to overcome the problems of traditional education, such as the influx of students, the accelerated progress if knowledge, the high cost, the increasing desire of people who want to learn, the in appropriate achieved results which do not meet the market needs, and the rigidity of the current educational system (Arab Organization for Education culture and sciences, 2002). Consequently, changes have taken place in some of the teaching and learning methods. E-learning is considered one of the modern methods in the present century which contributes to increasing the effectiveness of learners, and enables them to shoulder responsibility for his learning and becomes more able to practice discovery, analysis, synthesis and acquires higher level skills.

Hamdam (2007) indicated that e-learning system seeks to provide opportunities for those interested in continuing their higher education and to respond to the increased social demand, and to provide freedom of choice of for the learner in studying, it liberates the individual learner from the limitations of time and place to achieve continuous education and lifelong learning by employing multimedia much better than the traditional systems of the universities. It also contributes to solving the problems of the traditional higher education institutions which are unable to enroll the huge number of the students who want to continue their university education.

Several modern educational methods have been applied in Jordan, where as the ministry of education developed the first experimental project in 2005 at the level of integrating information and communication technology. The academic sector began to take care of e-learning through public and higher education. E-training covers international computer Driving license (ICDL) to meet the request of the ministry of education as well as the universities since 2000 .

Many conferences emphasized the necessity to focus on e-learning and it effective role in the educational process, such as: (International conference on e- learning, held in the city of Denver, USA, 1997) Its most important recommendations: e-learning and its media will be necessary, and common to give learners the skills needed for the future. E-learning will open new horizons for teachers and learners that were not available before and it is a promising solution for the needs of the students in the future (Al - Muhaisin, 1997) and the first international conference on e-learning and distance education which was held in Riyadh, 2009 recommended that the necessity for e-Learning and the conference which was held in Bahrain (2006) recommended the necessity to employ e-learning in developing curriculum. 


\section{Macrothink}

Hence, The researcher studied the status of e-learning usage at Jadara university and aimed to identify its advantages, dis advantages, and obstacles as perceived by Jadara University students.

\section{Statement of the Problem}

E-learning is considered to be one of the areas that witnesses the most rapid growth as a result of the scientific and technological development. As a result, the demand for integrating technology into educations has also increased, in order to build a generation capable of dealing with the new phases of the new era. This has led to an increased burden on the educational institutions and has given rise to the need to use information technology in the educational process. Based on what has mentioned above, the higher education institution are responsible for preparing and training the students to cope with the modern developments.

In the light of the few studies conducted on this topic at the Jordanian universities, the researcher tries to identify the status of e-learning at Jadara university and the obstacles that hinder its application form the perspectives of the university students in order to reach solutions to deal with those obstacles and challenges.

This study is an attempt to answer the following questions:

1. What is the status of e-learning usage from the students perspectives at Jadara University?

2. What are the advantages of e-learning from the perspectives of the students at Jadara university?

3. What are the negative effects of e-learning from the perspectives of the students at Jadara university?

4. What obstacles encounter e-learning from the perspectives of the students at Jadara university?

Are there significant differences between the students responses attributed to major (scientific, literary at Jadara university)?

\section{Purposes of the Study}

\section{This study aimed at}

1. Identifying the status of e-learning usage at Jadar university as perceived by students.

2. Identifying the positive advantages of using e-learning as perceived by Jadara university students.

3. Identifying the negative effects of using e-learning as perceived by Jadara university students.

4. Identifying the obstacles that encounter e-learning as perceived by Jadara university students. 
5. Identifying any significant differences between the students responses attributed to the major (scientific, literary) as Jadara university.

\section{Significance of the study}

\section{The significances of the study is indicated in the following points}

Identifying the status of e-learning usage as perceived by Jadara university students. $\quad .1$

The results of this study may contribute to providing a clear and practical vision of $\quad .2$ applying the latest technology to attain a better academic level at Jadara university.

To cape with the recommendations of the conferences and seminars which focused on $\quad .3$ developing education and emphasized the importance of the technological innovations to achieve better education at all levels.

To come up with proposals to improve the status of e-learning at Jadara university. $\quad .4$

To create the appropriate educational environment for the different majors at the $\quad .5$

university.

\section{Limitations of the study}

The Objective limitations: The study is restricted to identifying the status of e-learning in terms of: usage, advantage, Disadvantages and obstacles that hinder its application as perceived by Jadara university students.

Time and Place limitations: The study was conducted in summer semester for the academic year 2012 / 2013 in Jadara university random sample of the fourth year level students at Jadara university.

\section{Previous Studies}

Al - Moosa (2002) defined e-learning as: a method of teaching by using modern communication mechanisms such as computer networks and its multimedia like voice, images, graphics, research engines, electronic libraries and internet whether in distance learning or in the classroom Shamma and Ismail (2008) defined it as: a new technology based on providing an interactive learning environment centered around the learner, and well designed in advance in the light of instructional design principles appropriate for the open and flexible educations environment, using internet and digital technology resources, available for everyone any where and any time. Abdul Azis (2008) defined it as: a form of distance learning which depends on the possibilities and international networks instruments, Internet and computers to study a specific educational content through constant interaction with the teacher facilitator, the learner and the content.

E- learning means in the study: using modern communication mechanisms in education which includes using the computer, software, networks, multimedia such as voice, image, graphics, research engines, e-libraries, CDs, internet gates such as browser, email, websites, dialogue and debate forums, whether in distance learning or in the classroom. 
Savery, (2002) conducted a study to identify the perspectives of the students in integrating technology into education. The researcher used a questionnaire and distributed it to 4000 students and administrators in five colleges between 1998- 2001. The results of the study indicated that the college administrators used email by a ratio of $85 \%$, and the chalkboard by a ratio of $70 \%$, and the overhead projector by a ratio of $70 \%$, video presentations by a ratio of $45 \%$. The results also indicated that the college administrators lack understanding the principles of blending technology into education, which the students have better understanding the principles of integrating technology into education because they used this technology such as design software and instructional software, simulation and audio visual software by a ratio between $61 \%$ and $94 \%$, and they used email five times more than that of the administrators of the colleges.

Al- Nafeesah (2007) studied the status of the educational supervisors usage of e-learning in training teachers in the city of Jeddah, in Saudi Arabia. The population of the study consisted of (191) all the educational supervisors the results indicated the greats importance of the supervisors usage of e-learning in training the teachers in Jeddah. It also indicated that there were significant statistical differences between the means of the responses of the supervisors in using e- learning in training teachers attributed to the training courses they attended and their degree of familiarity with the computer.

Adeyinka et al. (2007) studied the information and communication technologies the secondary school teachers use, and the number of times of usage a week, the level of specifications of the available information's and communication technology at schools, the factors that hinder teachers from using such technology and their attitudes towards such technology, the descriptive analytical method was used by the researcher, The sample consisted of (700) secondary school teachers in the city of Abadan, the capital of (Oyo) state in Nigeria, aged between (25-45)years. The results indicated that the technologies used ranked as following: computer, video, digital cameras, As for the Internet and email they were not used at all. The number of hours of the usage was between (0-21) hours per week. The results also indicated that computers and software were out of order, the internet and instructional technology were missing at schools. The most important factors which hinder using information and communication technology were: lack of experience, insufficient knowledge of the appropriate software, ignorance of the role which instructional technology plays in secondary schools. The majority of the teachers agreed that using information and communication technology, is very difficult in the classroom and causes chaos, and makes teaching more difficult.

Abdul Karim (2008) studied the status of e-learning usage in Riyadh. The sample of the study consisted of (297) teachers. The most important findings were as follows: the availability of a website for each school. Female teachers were familiar with the computer usage including email and internet usages. The most important modes of email used was the cooperative learning. The study indicated that there were significant differences in e-learning usage attributed to major (scientific qualification, experience and the number of the training courses). It also indicated that the most important positive aspect of which raised the level of 
the teacher and his skills. The worst negative impact was social isolation of the learner because the learner spends a lot of lime using such technology.

Gulbahar (2008) conducted a study to identify the perspectives of teachers and student teachers in the college of education in Baskin university in Turkey. The sample consisted of (258) teachers and pre- service. The results indicated that there were three factors which influence the the usage of technology as follows: lack of the quantity and quality of technology lessons in the curriculum, lack of educated teachers willing to receive in-service training, lack of infrastructure, and shortage of electronic technology.

$\mathrm{Al}$ - Barakaty (2009) studied the status of e-learning in the training program for preparing and training teachers at Um Qura, mecca. The results indicated that $26.5 \%$ of the math students were ignorant of e-learning requirement such as (C.Ds, computer, equipped with a camera, software, multimedia, local network, data show projector, virtual classrooms, video conferences, and interactive video) lack of adequate training for students on e-learning devices and their requirements, and the lack of available electronic halls equipped with the necessary equipment.

\section{Methodology of the study}

The study was used depending on the nature of the descriptive analytical approach, and relied on the literature review and previous studies that enabled sthe researcher to access them, and for examining the status of e-learning usage.

\section{Method and Procedures}

The study used a descriptive analytical method which is suitable for this study, and questionnaire was distributed to the study sample and then collected and used appropriate statistical analyzes to get the results.

The target population of this study included all undergraduate fourth year students at Jadara University students in the academic year (2012-2013), with a total number of 1000 male and female students.

\section{Study sample}

A random sample of (100) male and female students was chosen from established population of those in science college and the literary college, constitute up to a rate $(10 \%)$ of the population for the year of (2012/2013). Table 1 shows the sample distribution.

Table 1. Sample of the study

\begin{tabular}{|l|l|}
\hline colleges & number \\
\hline Literary & 66 \\
\hline Science & 34 \\
\hline Total & 100 \\
\hline
\end{tabular}




\section{Al Macrothink}

The researcher was keen during the distribution of the questionnaires for the inclusion of the samples of the two colleges, (4) questionnaires from the science colleges students and (6) in the literary college students excluded from the study.

\section{Instrumentation}

To achieve the purpose of this study the researcher developed a questionnaire including (54) items. This instrument is comprised of dimensions as follow: first (the status of e-learning usage), second: (advantages of e-learning), third: (disadvantages of e-learning), fourth (obstacles of e-learning usage). Items of the instrument was rated on a five-point Likert type scale ranging from 5 (strongly agree), 4 (agree), and 3 (neutral), and 2 (disagree), and 1 (strongly disagree). This instrument was developed after an extensive review of previous research, and was given to arbitrators in the field of education psychology, measurement and evaluation and education technology at Jadara University. The arbitrators were asked to judge the instrument items in terms of comprehensiveness and adequacy, and clarity of items, and the suitability of the measure. The researcher took all the arbitrators suggestions into consideration and the final instrument consisted (54) items. And the reliability of the instrument was calculated according to the coefficient of Kronbach alpha which was (80.1).

\section{Results and Discussion}

Question 1: What is the status of e-learning usage as perceived by Jadara University students?

Table 2. Means and Standard Deviation for the status of e-learning usage

\begin{tabular}{|c|c|c|c|}
\hline \multicolumn{2}{|l|}{ field } & Mean & $\begin{array}{l}\text { Standard } \\
\text { Deviation }\end{array}$ \\
\hline \multicolumn{2}{|l|}{ Items } & 2.53 & 0.51 \\
\hline \multirow{6}{*}{$\begin{array}{l}\text { Word basic } \\
\text { skills }\end{array}$} & Writing quickly, conservation and retrieval & 2.31 & 1.29 \\
\hline & $\begin{array}{l}\text { Printing in all forms and the use of most lines } \\
\text { are available }\end{array}$ & 3.02 & 0.57 \\
\hline & Attach images and various drawings in the text & 3.12 & 0.63 \\
\hline & Design tables, reports and questionnaires & 3.18 & 1.37 \\
\hline & Different drawings & 3.04 & 0.43 \\
\hline & $\begin{array}{l}\text { Directed texts, images and all drawings on } \\
\text { printer }\end{array}$ & 2.88 & 0.78 \\
\hline \multicolumn{2}{|c|}{ I am able to deal with the Excel program } & 2.19 & 0.50 \\
\hline \multicolumn{2}{|c|}{$\begin{array}{r}\text { I can make an offer for a particular topic through a Power Point } \\
\text { program }\end{array}$} & 2.66 & 1.29 \\
\hline
\end{tabular}




\begin{tabular}{|c|c|c|}
\hline I can manage electronic files (open, delete, receive, send, save) & 3.77 & 0.58 \\
\hline $\begin{array}{r}\text { The existence of the Internet is always available at your service in } \\
\text { the college }\end{array}$ & 2.92 & 0.64 \\
\hline I use the Internet for the purposes of scientific research & 2.43 & 1.32 \\
\hline $\begin{array}{r}\text { Teachers use a lot of information from out of the book, which } \\
\text { enriches the lecture }\end{array}$ & 2.48 & 0.50 \\
\hline The research in electronic libraries useful for topics subjects & 2.67 & 0.89 \\
\hline $\begin{array}{r}\text { Teachers encourages students to use the Internet to communicate } \\
\text { and share experiences with colleagues }\end{array}$ & 2.44 & 1.02 \\
\hline $\begin{array}{l}\text { Teachers lectures are broadcast on live video and audio from } \\
\text { anywhere, where you can follow up on it from anywhere also }\end{array}$ & 2.19 & 0.77 \\
\hline $\begin{array}{r}\text { Teachers use software (PowerPoint, Flash .... ) in the educational } \\
\text { process }\end{array}$ & 2.67 & 0.61 \\
\hline $\begin{array}{r}\text { Teachers use video and audio recordings in the educational } \\
\text { process }\end{array}$ & 2.32 & 0.96 \\
\hline The existence of a special site on the Internet easy to use & 3.75 & 1.04 \\
\hline I have a private e-mail & 3.86 & 1.25 \\
\hline I have sufficient knowledge of using the Internet and e-mail & 3.91 & 1.11 \\
\hline I use e-mail to communicate with my colleagues & 4.01 & 0.96 \\
\hline I use e-mail to communicate with my teachers & 2.11 & 0.64 \\
\hline my teachers ask to send my assignments to their e-mail & 2.15 & 1.02 \\
\hline Enough halls dedicated in the college for e-learning & 2.45 & 0.65 \\
\hline $\begin{array}{r}\text { I can build a favorite Web sites on my computer in an orderly } \\
\text { manner which is indexed }\end{array}$ & 2.85 & 0.52 \\
\hline I am able o deal with the computer & 4.02 & 0.50 \\
\hline the status of e-learning usage & 2.89 & 1.29 \\
\hline
\end{tabular}

Table (2) shows that the status of e-learning usage was moderate with the mean of (2.89) and (1.29) standard deviation. The highest mean was (4.01) for the item "I use e-mail to communicate with my colleagues" received high level of use and the lowest mean was (2.11) for the item "I use e-mail to communicate with my teachers" received low level of use. 
Question 2: What is the advantages e-learning usage as perceived by Jadara University students?

Table 3. Means and Standard Deviation for the advantages e-learning usage

\begin{tabular}{|r|l|r|}
\hline Items & mean & $\begin{array}{r}\text { Standard } \\
\text { Deviation }\end{array}$ \\
\hline Raise the level of achievement among students & 4.31 & 0.52 \\
\hline Enables students to self learn & 3.87 & 0.82 \\
\hline Students can communicate with the teacher anywhere and & 3.55 & 0.54 \\
\hline anytime via e-mail & & 0.67 \\
\hline Increases computer skills experience for the students & 4.02 & 1.19 \\
\hline Help students to retain information for a long period & 4.55 & 1.33 \\
\hline Increases the motivation of students to study & 3.66 & 1.24 \\
\hline Take into account individual differences among students & 3.54 & 1.26 \\
\hline Works to create real learning environment & 4.33 & 0.78 \\
\hline Gives immediate and direct feedback & 3.04 & 0.78 \\
\hline Contributes to the activation of active learning & 4.25 & 1.33 \\
\hline Develop critical and creative thinking & 3.75 & 1.44 \\
\hline Develop IT skills & 4.12 & 0.89 \\
\hline adurn ability to use modern technologies tools & 3.46 & 0.62 \\
\hline
\end{tabular}

Table (3) shows that the mean for the advantages of e-learning usage was moderate with the mean of (3.89) and standard deviation was (.62). The item "help students to retain information for a long period" received highest mean which was (4.55), and the item "gives immediate and direct feedback" received lowest mean $(3,04)$.

Q3: What the disadvantages of e-learning usage as perceived by Jadara University students? 
Table 4. Means and standard deviation for the disadvantages of e-learning usage

\begin{tabular}{|c|c|c|}
\hline Items & mean & $\begin{array}{l}\text { Standard } \\
\text { Deviation }\end{array}$ \\
\hline Increases the isolation of students & 3.79 & 0.78 \\
\hline Disabled devices hinders the educational process & 4.05 & 0.76 \\
\hline $\begin{array}{c}\text { The difficulty of applying the methods and the appropriate } \\
\text { calendar tools }\end{array}$ & 3.54 & 1.03 \\
\hline increases the burden between teachers and students & 4.06 & 0.96 \\
\hline $\begin{array}{r}\text { Prolonged time sitting in front of a computer causes a lot of } \\
\text { diseases }\end{array}$ & 4.11 & 1.02 \\
\hline $\begin{array}{r}\text { E-learning focuses on the senses of hearing and sight without the } \\
\text { rest of the senses }\end{array}$ & 3.22 & 1.35 \\
\hline $\begin{array}{l}\text { E-learning reduces the presence of humanitarian and human } \\
\text { relations between the teacher and students and among students } \\
\text { themselves }\end{array}$ & 3.44 & 0.74 \\
\hline disadvantages of e-learning usage & 3.74 & 1.05 \\
\hline
\end{tabular}

Table 4 shows that the mean for the disadvantages of e-learning usage was moderate with the mean of (3.74) and standard deviation was (1.05). The item "prolonged time sitting in front of a computer causes a lot of diseases" received highest mean which was (4.11), and the item " e-learning focuses on the senses of hearing and sight without the rest of the senses " received lowest mean (3.22).

Q4: What are the obstacles that face the e-learning usage as perceived by Jadara University students? 
Table 5. Means and standard deviation for the obstacles that face e-learning usage

\begin{tabular}{|c|c|c|}
\hline Items & mean & $\begin{array}{l}\text { Standard } \\
\text { Deviation }\end{array}$ \\
\hline E-Learning takes a lot of time and effort & 3.76 & 0.70 \\
\hline $\begin{array}{r}\text { The inexperience teachers and students with e-learning } \\
\text { technology tools }\end{array}$ & 3.73 & 0.55 \\
\hline Classrooms are not dedicated to the application of e-learning & 3.56 & 0.85 \\
\hline Neglect of the continuous maintenance of computers & 3.81 & 1.29 \\
\hline Interruption of the Internet for long periods of time & 3.55 & 1.33 \\
\hline The weakness of students' skills in Internet and Computers & 3.54 & 1.34 \\
\hline The difficulty to teach large number of students via the Internet & 3.22 & 1.36 \\
\hline $\begin{array}{c}\text { Non- equipped computer lab with the necessary printers, } \\
\text { headphones and printing paper }\end{array}$ & 4.45 & 0.78 \\
\hline The delay in the opening pages of the Internet program & 3.89 & 0.97 \\
\hline $\begin{array}{r}\text { The use of computers and the Internet reduces communications } \\
\text { between the student and teacher }\end{array}$ & 3.02 & 1.34 \\
\hline Obstacles that face e-learning usage & 3.96 & 1.20 \\
\hline
\end{tabular}

Table 5 shows that the mean for the Obstacles that face e-learning usage was moderate with the mean of (3.96) and standard deviation was (1.20). The item "Non- equipped computer lab with the necessary printers, headphones and printing paper "received highest mean which was (4.55), and the item " the difficulty to teach large number of students via the Internet" received lowest mean (3.22).

Q5: Is there any significant difference in the use of e-learning and its advantages and disadvantages and obstacles in regard to specialty (literary, scientific)?

An independent sample t-test was conducted to test significance difference between science and literary students in regards to internet use, advantages, disadvantages and obstacles. 
Table 6. T test of science and literary students

\begin{tabular}{|c|c|c|c|c|c|}
\hline Internet & Specialty & Number of subjects & Mean & t-value & $\mathrm{P}$ \\
\hline \multirow{3}{*}{ Usage } & Scientific & 30 & 3.89 & \multirow{3}{*}{7.06} & \multirow{3}{*}{0.00} \\
\hline & & & & & \\
\hline & Literary & 60 & 2.54 & & \\
\hline \multirow{2}{*}{ Advantages } & Scientific & 30 & 4.02 & \multirow{2}{*}{9.34} & \multirow{2}{*}{0.035} \\
\hline & & & & & \\
\hline \multirow{4}{*}{ Disadvantages } & & & & & \multirow{4}{*}{0.24} \\
\hline & Scientific & 30 & 3.65 & \multirow{3}{*}{1.40} & \\
\hline & & & & & \\
\hline & Literary & 60 & 3.89 & & \\
\hline \multirow{3}{*}{ Obstacles } & Scientific & 30 & 3.74 & \multirow{3}{*}{1.13} & \multirow{3}{*}{0.64} \\
\hline & & & & & \\
\hline & Literary & 60 & 3.89 & & \\
\hline
\end{tabular}

Table (6) shows that there were significant difference between the mean of the two groups in term of internet use, and advantages of the internet in favor of science students the ( $\mathrm{t}$ ) value was (7.06) and the p (0.00), (t) value (9.34) and (p) 0.035 respectively. Also the table (6) indicated that there were no significant difference between the mean of two groups in term of internet disadvantages and internet obstacles.

\section{Conclusion}

There was a convergence of views of students to use e -mail to communicate with members of the faculty teaching, and sending duties on the e-mail, and broadcast lectures with live video and audio from anywhere, to enable the student to follow-up from any location) was done largely invery small fraction, most students are proficient in dealing with the computer, and be able to manage electronic files: (open, delete, receive, send, save), also agreed that the members of the sample that the most positives of e-learning was (allow students of self-learning, increases the experience and skills of the students in computer, as for the cons of e-learning has assured students (causing prolonged sitting in front of a computer a lot of diseases, reduces the presence of electronic illiteracy among parents to follow their children electronically), but the most important obstacles to e-learning from the view point of students (classrooms is dedicated to the application of e-learning).

The study confirmed the existence of a difference statistically significant between the average scores of students on the axis (the extent of the use of e-learning, and disadvantages) depending on the variable specialization in favor of scientific specialization, and the lack of a 


\section{Macrothink Institute ${ }^{\mathrm{TM}}$}

difference statistically significant between the average scores of students on the axis (the advantages of e-learning, and its constraints) depending on the variable Specialization.

\section{Proposals of the study}

- Providewell working Internet networkwhich are available for allof the students in each faculty of the colleges.

- The inclusion of curriculums dealing with e-learning in all branches of the Jordanian universities.

- Provide appropriate training opportunities for university students on the use of computers and the Internet, and the use of different e-learning technology.

- Establish training courses in universities for International Computer Driving License ICDL, and the license of the International Computer and Internet IC3 and specialized courses dealing with different kinds of networks.

- Publication of scientific and technical awareness about the benefits of e-learning.

- Adoption of educational and scientific strategies in the field of e-learning.

- Work on the employing of e-learning in the field of self-learning.

\section{References}

Al-Barakati, \& Neven Bint Hamza Sharaf. (2009). status of using electronic learning by math students in the Educational Preparation Program at Umm Qura University in Holy Mecca, The Scientific Educational Journal, 2(12), Cairo.

Hamdan, Mohammad Sa'eed. (2007). The international and Arab experiences in Electronicthe learning, Al-Qudus Open University / The Palestinian Journal for Open and Distance Educational, I, No. 1, December.

Shama, Nader Saed, \& Ismael, Sameh Sa'eed. (2008). Introduction to Educational Technology, Amman, Dar Al-Fiker.

Abdul Aziz, \& Hamdy Ahmed. (2008). E-learning philosophy - principles - tools and applications, Amman, Dar Al-Fiker.

Abdul Kareem, \& Masha'el Abdul Aziz. (2008). Status of using e-learning in Private schools in Riyath Saudi Arabia, unpublished MA thesis, college of Education, King Saud University.

Al-Mhasin, Ibrahim Abdullah. (2003). A paper Presented in the Future School at King Saud University entitled, The e-learning.... Entertainment or necessity, during the period from 16-17 Rajab, 1423 Hijri.

The Arab Organization for Education Culture and sciences. (2002). The Third Confernce for the EDUCATION Arab Ministers, Algeria. 


\section{Macrothink}

Journal of Studies in Education

ISSN 2162-6952

2015, Vol. 5, No. 2

The First international conference for the Electronic Education, Bahrain 17-19. (April,2006). conference Recommendations. The Educational and Psychological Journal, 3(7), Bahrain Univ, P. 273.

The Eighthscientific conference. (2001). The Electronic School, The Egyption society for Educational Technology, October, PP: 506-512.

Almusa, Abdullah Bin Abdul Aziz. (2002). Electronic Learning : concepts, characteristics, Uses, and Barriers A paper presented in the Future School Forum, King Saud Univ., Reyath.

Al Nafeesah, \& Kahalid Abdul Rahman Bin Ibraheem. (2007). The Status of Electronic Learning Usage in Training Teachers in Jaddah City, College of Education, Um Qura Univ., College of Education.

Savery, R. John. (2002). Faculty and Student Perceptions of Technology Integration in Teaching, The Journal of Interactive Online Learning, 1(2), ISSN: 1541-4914.

Adeyinka, T. and Adedeji, T and Majekodunmi, T and Lawrence, A and

Ayodele, A. (2007). An assessment of secondary school teachers uses of ICT'S; Implications for further development of ICT'S uses in Nigerian secondary schools. Turkish online journal of educational technology, 6(3). http://tojde.anandolu.edu.tr

Gulbahar,Yasemin. (2008). ICT using in higher education: A case study on pre- service teachers and instructors, Turkish online journal of educational technology, 7, 1, Article 3, http://tojde.anandolu.edu.tr. 